\title{
Metonymies of Ethnobotany and the Fellowship Discourse of Sagrada Familia Healers in Irosin, Sorsogon, Philippines
}

\author{
Jesur Cyrill M. Conde \\ Ateneo de Naga University
}

\section{Abstract}

The study explores the metonymies of plants and spirits in the ethnobotanical rituals of the Sagrada Familia healers in the village of Patag in Irosin, Sorsogon, Philippines. It exposes how these metonymies construct a fellowship of discourse that represents the cultural models of surviving poverty, sickness, and disasters in the calamity-stricken town. It explores the interdisciplinary focus on language, culture, history, and plants in the field of Philippine cognitive ethno-botany. Using grounded theory methodologies, the study relies on five months of field research with participant observation and digital documentation (November 2017-March 2018). It employs substantive language coding focusing on metonymies and on theoretical coding which links the functions of metonymies to preservation of traditional ecological knowledge and cultural models of survival. The paper links language codes to culture to fill gaps in the technical and utilitarian studies in Philippine ethno-botany. In the Sagrada Familia group, mediums called luklukans invoke spirits that provide instructions on the medicinal use of plants. These spirits manifest metonymically through the sight, sound, smell, touch, and taste of plants and communicate directly to sick people through the voice of possessed mediums. Material practices and oral literatures containing the metonymies exist in the whole group as doctrines that unite them as members of a fellowship of discourse. This 
plant-centered fellowship perpetuates a discourse on happiness in simplicity, kinship, other-centeredness, acceptance of fate, and oneness with nature in the disaster-prone town of Irosin located inside a caldera.

\section{Keywords}

Metonymy, Ethnobotany, Sagrada Familia , Irosin 


\section{Background}

Irosin, Sorsogon, Philippines

Located at the southeastern end of Luzon Island in the Philippines, Irosin in the province of Sorsogon is the only landlocked town inside a caldera in the Bulusan volcanic complex. A caldera is formed when a summit of a volcano collapses into its empty magma chamber (Okuno et al. 734). According to 2017 municipal records and oral history, the Irosin caldera has been rich in flora and fauna since the $18^{\text {th }}$ century, attracting migrants from other towns of Sorsogon ("History: a Brief History of Irosin" 2). However, Irosin is prone to the lahar flow from a neighboring active volcano-Mt. Bulusan. Furthermore, the presence of waving rivers crisscrossing from the mountains down the caldera causes flood and riverbank erosion. Its location makes Irosin a town that is most vulnerable to natural disasters and calamities in the whole province of Sorsogon (Ramos 1). According to records of Philippine Institute of Volcanology and Seismology (PHILVOCS), Mt. Bulusan erupted 39 times from 1852 to 2017 (Volcano Information Materials 1).

\section{The Oral History and Culture}

\section{of Sagrada Familia in the Village of Patag}

The reliance on plants and spirits to survive poverty, sicknesses, and disasters is a cultural trait of the town of Irosin. Moreover, of the twenty eight villages in the town, the village of Patag can be a representative of this trait. Patag is situated at 12.7274, 124.0572, in the island of Luzon. Elevation is at 255.9 meters or 839.6 feet above mean sea level. It shares boundaries with four barangays-santo Domingo, Bagsangan, Mapaso, and Cawayan (Patag, Irosin, Sorsogon Profile-Phil Atlas 2). There are healers in other villages practicing their craft as individuals; but Patag has a group of organized healers: the Sagrada Familia. In the belief of some sick people in Patag, these healers can cure physical ailments by using plants recommended by spirits.

During focused group discussion with the researcher, members of Sagrada Familia who did not wish to be identified, narrated their oral history. They claimed that the group started in the 1980s when Lolo Empinito, a 
spirit residing in the cave of Marilag as a hermit, pitied a poor and sick single mother in the village of Patag. They believed that Lolo healed the woman and made her his luklukan or medium. The group claimed that since then, the spirit of Lolo enters and controls the body of the luklukan to perform healing rituals. This made the luklukan one of the most popular healers in the town. Under the supervision of the luklukan, some of her patients coming from different villages became permanent apprentices with the role of mixing parts of different healing plants.

The same informants claimed that two spirits of dead people named Dr. Jose Rizal and Dr. Felipe Salvador started to possess the luklukan to help Lolo Empinito heal more patients. The spirit of Jose Rizal, an eye and kidney doctor, is believed to perform operations using the body of the luklukan who is assisted by some apprentices. The other spirit, the dentist Dr. Salvador, also performs some surgical procedures. The Sagrada Familia members did not give the researcher the permission to know the difference between Rizal and Salvador and to witness surgical operations.

After some time, the luklukan and the apprentices decided to call themselves Sagrada Familia or sacred family because they have developed a strong kinship with each other. When the luklukan died in 2013, Lolo Empinito chose her daughter, now in her thirties, to become the new luklukan.

At the time of the research from November 2017-March 2018, Sagrada Familia had thirty members. The cultural influence of the group, however, extends beyond the members. The families of each member and the sick people healed by the group over several decades share the belief in the powers of plants and spirits to help people survive disasters, poverty, and illnesses. This belief is articulated by oral narratives and material practices.

The problem is that there is no publication on the culture of Sagrada Familia. The ways the Sagrada Familia relies on plants and spirits through metonymic narratives and material practices provide examples and models of survival culture. A research methodology in ethnobotany that explores how figurative language articulates and perpetuates herbal healing practices and reliance on spirits is a way to explore this culture of survival with details and depth. The bigger problem is that this methodology has not yet 
been done in Philippine ethnobotany. It is this research gap that this study attempts to probe.

The study aims to describe the function of metonymies of plants and spirits in the ethnobotanical rituals of the Sagrada Familia healers; expose how these metonymies construct a fellowship which survives poverty, sickness, and disasters through the reliance on plants, supernatural beings, kinship, and oneness with nature; and link metonymic language codes to culture to fill gaps in the technical and utilitarian studies in Philippine ethnobotany.

\section{Metonymy}

This paper describes metonymy as a trope perceived by multiple human senses (Orden 5); as a part of collective knowledge in a particular culture (Surrete 557-575); and as material practice determined by particular worldviews (Paradis 245-264).

According to Orden,

in metonymy, a word or phrase denoting an object, action, institution, etc., is functionally replaced with "a word or phrase denoting one of its properties or something associated with it.... Any medium that bears an icon-take the women's and men's restroom signs, for instance-is inherently metonymic: these crude sets of lines-either triangular, for women, or rectangular, for men, each topped by a circle-convey through logic ... the image of a woman's or a man's body....

The bygone days of radio plays introduced ... the sound effects artist, to the world of image-making. In a sense, the . . . artist deals exclusively in tropes; sound effect produced on radio is at heart a metonymy; the audible parts-clapping hooves, or thunder-each signify a real whole: horses at a gallop, a storm blowing in. ... As a final example, consider the remarkable medium of perfume advertisements. In these, fragrance is given an image. . . Metonyms are more grounded in our experience than metaphors, since they involve direct associations. (5)

Metonymy is perceived by multiple human senses. The examples given are visual, auditory, and olfactory. The perception happens since the language of metonymy is associated with collective knowledge that has been established 
even before the modern technology of the mass media. Loza et al. (15891592) show this collective perception of metonymy in the village of Cagliliog in Tinambac town, Camarines Sur province, Philippines. In Cagliliog, residents believe in the presence of supernatural beings called the Tawong Lipod. Invisible to human senses, the Tawong Lipod manifest themselves to people and control beliefs and practices through representative metonymies like sounds of animals, dreams, and physical and mental ailments.

Metonymy is part of epistemic community knowledge. In fact,

[t] he epistemic is what we believe ourselves to know. . . . It is in a sense primitive knowledge prior to socialization of categorized knowledge or the verification of theory formulated knowledge. Metonymy is an association of meanings determined by culture. Semantics are the meanings of symbols or terms-their sense of reference. (Surrete 560)

Metonymy transcends academic semantics since it is both epistemic or relating to knowledge, and encyclopedic. It is encyclopedic for it is associated with multiple meanings-cultural objects, material practices, and beliefs. The association is constructed and perpetuated by the culture of a community and not simply a semantic definition by scholars (Surrete 564).

Metonymic knowledge is not primarily a linguistic ornament; it is a basic cognitive process that is pervasive in language and thought (Paradis 245). The function of metonymy is determined by ontology or how human beings view the world. Ontologically, human beings view the world as three orders of entities. The first order includes physical objects like people, plants, animals, and natural objects; the second are events, processes, and states; and the third are abstract entities that are outside both space and time. Entities under the first order have the deepest manifestation of existence; they exist at any point in time and are publicly observable (Paradis 248).

This paper relies on the theory of metonymy to describe the ethnobotanical practices of Sagrada Familia and to relate these practices to culture and history. Following Orden (5), this paper describes the cultural practices of Sagrada Familia articulated through metonymies of images, sounds, smell, taste, and touch. Using Surrete's theory, it relates these multiple metony- 
mies to various cultural practices that are part of community knowledge. Appropriating Paradis (245-264), it explores how these metonymic practices reflect the Sagrada Familia's three ways of seeing the world: objects, events, and abstract entities.

This research documented, described, and analyzed metonymies through grounded theory methodologies.

\section{Grounded Theory}

Grounded theory is "a general methodology of analysis linked with data collection that uses a systematically applied set of methods to generate an inductive theory about a substantive area” (Glaser qtd. in Evans 37). It is a qualitative research design that permits "the researcher to get close to the data, to know well all the individuals involved and observe and record what they do and say" (Mintzberg qtd. in Evans 37).

\section{Participant Observation}

The main study design under grounded theory is participant observation. According to Filipino folklore scholars E. Arsenio Manuel (22-35) and Florentino Hornedo (1-10), participant observation is the researcher's deep immersion in his or her research locale. He or she is able to participate in the cultural activities like a member of the community.

The researcher has been married for nineteen years to Maria Aurora Azurin Conde, a native of Irosin, Sorsogon. During long vacations from his teaching work in Ateneo de Naga University, he lives in Irosin. For this particular project, the researcher was introduced by members of the Azurin clan to the leaders of the Patag-based Sagrada Familia. With the consent of the Sagrada Familia members, the researcher participated as an observer in the rituals that were held during the five-month duration of the project.

The rituals of the Sagrada Familia are held every Tuesday, Friday, and Sunday in Barangay Patag, Irosin, Sorsogon. The researcher, with the help of native assistants, documented rituals and oral narratives with digital cameras and recorders. Sagrada Familia members, however, did not give permission to publish either digital or printed pictures. 
After his constant presence in various gatherings from healing rituals to parties, the Sagrada Familia members eventually allowed the researcher to converse with the spirit of Lolo Empinito, whom they believed to be inside the body of the luklukan. The luklukan called the name Lolo Empinito. Then the luklukan's body shook convulsively, a sign, according to the group the spirit of Lolo was already inside her. Then, the luklukan interrogated the researcher about the objectives of the project. Responding that he was aiming to share with the academe the benevolent practices of the group, the researcher was allowed by the luklukan to record the latter's voice. Prohibiting the use of any camera, the luklukan talked to the researcher about the history of the group and the uses of healing plants.

Nevertheless, the researcher was not allowed to witness the surgical operations allegedly done by the spirit of Dr. Jose Rizal while inside the body of the luklukan. Sagrada Familia members believe that Rizal is another spirit that possesses the body of the luklukan simultaneously with Lolo to perform surgical operations. According to the group, only the most senior members are allowed to witness the operations. These senior members claimed that all operations were successful and they themselves were patients who have undergone these procedures. They refuse, however, to reveal details.

The researcher conducted interviews and engaged in spontaneous conversations with the members of the Sagrada Familia. The interviews were done inside the home of the luklukan in Patag which serves as a rendezvous for the group. Additional interviews were done in the homes of several senior members who act as main assistants of the luklukan during rituals.

The researcher transcribed and translated the data from Irosin language to English with the help of an English teacher who is a native of Irosin. In some instances, the translation is not word for word. The peculiar meanings of key words are discussed elaborately in paragraphs in varied sections of the paper.

\section{Grounded theory coding}

This paper uses the coding method in classical coding theory (CGT). CGT employs substantive and theoretical coding: 
In substantive coding, the researcher works with the data directly, fracturing and analyzing it, initially through open coding for the emergence of a core category and related concepts and then subsequently through theoretical sampling and selective coding of data to theoretically saturate the core and related concepts." (Holton qtd. in Evans 40)

Employing substantive open coding, the researcher read all of the transcribed data in the Irosin language to look for patterns of communicating meanings that can lead to the emergence of a core category and related concepts. The open coding unveiled the presence of metonymy as an essential form of communication that defines the nature and functions of the Sagrada familia group.

Theoretical coding follows through three steps. The first step links the metonymies of ethnobotany to the core category of fellowship of discourse (Foucault 225). The whole group of Sagrada Familia healers as well as their patients who come from different villages in the town of Irosin belong to a fellowship of discourse with a hierarchy of leaders and particular roles of members. The paper further discusses the power relations between the Sagrada Familia group and the town community in general, particularly the other religious groups and the local government. Metonymies about the powers of plants and benevolent spirits implant beliefs in the members of the fellowship. These beliefs solidify into discourses with corresponding material practices.

The second step relates the ethnobotanical metonymies of fellowship of discourse to the role of oral literature in the preservation of traditional ecological knowledge (Berkes 1251) and cultural models (Borchgrevink 226). Preserved by oral literature and material practices, cultural models of traditional ecological knowledge are ways of surviving poverty, sickness, and disasters in the Irosin community.

The third step compares and contrasts the ethnobotanical metonymies of fellowship of discourse with studies of ethnobotany in the Philippines. It further compares this research with studies on Philippine culture that directly or indirectly show the social function of metonymies. It ends by 
recommending the expansion and deepening of Philippine ethnobotany by appropriating related language and culture methodologies.

\section{Fellowship of Discourse}

The open coding unveils the functions of multiple metonymies that lead to the emergence of related core categories of fellowship of discourse and ethnobotany. In the Sagrada Familia group, metonymies of ethnobotany construct, preserve, and reproduce a fellowship of discourse with its own cultural models and worldview. Discourse is a way of thinking articulated through verbal and non-verbal language; it reflects, creates, and perpetuates thoughts, feelings, actions, and relationships of people (Keller 1-28; Foucault 215-254).

The French theorist Michel Foucault (215-254) states that a group of people controlled by discourse functions as a fellowship that preserves and perpetuates the discourse through language and material practices. Inside the fellowship, there are doctrines, rules and regulations, secrets, and exclusion and rejection mechanisms. To quote Foucault:

A rather different function is filled by 'fellowships of discourse', whose function is to preserve or to reproduce discourse, but in order that it should circulate within a closed community, according to strict regulations. ...

The speaking subject is involved through ... rules of exclusion and the rejection mechanism ... . Doctrine links individuals to certain types of utterance while consequently barring them from all others. (225)

\section{Cognitive Ethnobotany}

By exploring the functions of metonymies in a fellowship of discourse, this paper focuses on the cognitive ethnobotany of the Sagrada Familia group in the village of Patag in the town of Irosin, province of Sorsogon, Philippines. In broad terms, ethnobotany is the study of the relationships between plants and people. The two fields labeled "ethno" and "botany" cover a spectrum of interests, ranging from archaeological investigation of ancient civilization to bioengineering of new crops. Most studies are concerned with the ways 
indigenous people use and view plants. Those uses and views can provide deep insights into the human condition (Balick and Cox 1-10).

Based on Balick and Cox (1-10), studies in the field of ethnobotany can be classified as utilitarian and as cognitive. The utilitarian approach involves the collection and identification of plant species used for different reasons in a particular community. It also elucidates the methods used in the production and processing of these plants. In contrast, cognitive ethnobotany focuses on the cultural symbolism and social structure to examine the ways plants are perceived in a particular community.

\section{The Functions of Metonymies in the Sagrada Familia Worldview}

The researcher has observed that the worldview in general of Sagrada Familia is grounded on metonymies. They believe that supernatural beings intervene in human affairs through metonymic representations. Below is a table of these entities, their representing metonymies, and their roles in the Sagrada Familia fellowship. 
Table 1. The Entities, Roles, and Metonymies in the Sagrada Familia

\begin{tabular}{|c|c|c|}
\hline Supernatural Entity & Representing Metonymy & $\begin{array}{l}\text { Role in the Fellowship of } \\
\text { Ethnobotanical Discourse }\end{array}$ \\
\hline Lolo Empinito & $\begin{array}{l}\text { Auditory } \\
\text { The tik-tik sound of a lizard } \\
\text { The voice of a medium } \\
\text { called luklukan } \\
\text { Visual } \\
\text { The trembling of the } \\
\text { luklukan } \\
\text { The fierce expression in the } \\
\text { eyes of the luklukan }\end{array}$ & $\begin{array}{l}\text { Chief Herbal Doctor } \\
\text { Prescribes healing plants through the } \\
\text { medium luklukan } \\
\text { Provides power to the luklukan to drive } \\
\text { away negative spirits causing illnesses } \\
\text { Gives lectures about service, other-cen- } \\
\text { teredness, peace in fatalism } \\
\text { Gives direction about places of rituals } \\
\text { Locates missing persons through clair- } \\
\text { voyance } \\
\text { Articulates prohibitions (taking pictures } \\
\text { and videos) } \\
\text { Predicts calamities and disasters } \\
\text { Leads and prescribes rituals against } \\
\text { calamities and disasters }\end{array}$ \\
\hline Luklukan & $\begin{array}{l}\text { Visual } \\
\text { Changing voice INTO } \\
\text { WHAT? } \\
\text { Trembling OF THE BODY? } \\
\text { Sharp expression of the eyes }\end{array}$ & $\begin{array}{l}\text { Is the medium of spirits; } \\
\text { Leads healing rituals through powers } \\
\text { from spirits } \\
\text { Performs x-ray ritual of himagat } \\
\text { Promotes unity and camaraderie } \\
\text { through social and spiritual activities. }\end{array}$ \\
\hline $\begin{array}{l}\text { Spirit of Dr. Jose } \\
\text { Rizal }\end{array}$ & $\begin{array}{l}\text { Visual and Touch } \\
\text { Skill of hands of luklukan to } \\
\text { perform medical operations }\end{array}$ & $\begin{array}{l}\text { Ophthalmologist, Nephrologist, and } \\
\text { Surgeon } \\
\text { Possesses the body of luklukan to per- } \\
\text { form medical operations. }\end{array}$ \\
\hline $\begin{array}{l}\text { Spirit of Dr. Felipe } \\
\text { Salvador }\end{array}$ & $\begin{array}{l}\text { Visual and Touch } \\
\text { Skill of hands of the luklukan } \\
\text { to perform dental proce- } \\
\text { dures }\end{array}$ & $\begin{array}{l}\text { Dentist } \\
\text { Possesses the body of luklukan to per- } \\
\text { form dental missions }\end{array}$ \\
\hline Tawo sa lipod & $\begin{array}{l}\text { Touch } \\
\text { Various illnesses }\end{array}$ & $\begin{array}{l}\text { Main enemy of the fellowship of Sagrada } \\
\text { Familia } \\
\text { Cause of various illnesses }\end{array}$ \\
\hline
\end{tabular}


Sagrada Familia members depend on spirits to survive sickness, poverty, and disasters. In the table above, the presence of these spirits is articulated by various metonymies of sight, sound, and touch. This metonymic presence is a core element that binds the members of Sagrada Familia as a fellowship of discourse.

Sagrada Familia members believe that the spirit of Lolo Empinito is their leader. During healing rituals, they claim that Lolo Empinito enters the body of a medium called luklukan. The spirit of Lolo provides the luklukan the power to detect illnesses of patients through various rituals and to prescribe herbal treatment.

As observed by the researcher, the luklukan invites Lolo to enter her body. After a few seconds, the luklukan's body trembles. Her facial expression changes and her eyes become fierce-signs or non-verbal metonymies representing Lolo Empinito possessing a human body. I decide to delete the preceding sentence in blue letters because I was in a state of fear in the observation and my description in this part may not be very accurate. Then, the female luklukan speaks with a high-pitched voice that seems to be genderless. With this voice, the luklukan faces a patient, provides diagnosis, and explains how to use different plants for treatment.

If the patient suffers from severe ailment that needs an operation, the luklukan calls the spirit of Dr. Jose Rizal to enter her body and perform the operation. In case of dental problems, the luklukan invites the spirit of the dentist Dr. Felipe Salvador.

The members of Sagrada Familia have the minor roles of preparing concoctions of medicinal plants prescribed by the luklukan. They also give hope to patients by sharing stories of how they were healed by spirits and plants. The luklukan chooses a few most trusted members to assist in the operations done by Dr. Jose Rizal or Dr. Felipe Salvador.

Sagrada Familia members believe that Lolo Empinito, functioning through the body of the luklukan, is a great source of hope. The luklukan predicts the coming of calamities and recommends the ritual of eggs to make spirits prevent disasters. She instructs Sagrada Familia members to go to 
the nearby forest, enter the cave near the waterfalls, put some eggs on the ground, and light some candles. Then she silently prays to the spirits.

Furthermore, according to Sagrada Familia members, Lolo is omnipresent. Anybody anywhere in the world who believes in Lolo can ask him for help. The believer should just call the name of Lolo Empinito three times, orally or silently. Then, if a lizard answers with its peculiar sound, it means Lolo is present.

The general observation of the researcher is that Lolo Empinito and the other spirits cannot be perceived by the human senses except in the metonymies representing them. The main metonymy is verbal and auditory: it is the changed voice of the luklukan representing Lolo Empinito. The sound of the lizard and the other metonymies of sight like the dexterity of her hands during surgical operations are subordinate metonymies which augment the power of the voice.

Finally, the benevolent social power of the voice is mainly dependent on the medicinal plants that it prescribes. According to the voice, some of the ailments of humans are caused by malevolent spirits called Tawo sa lipod, but most illnesses are caused by too much intake of animal meat and lack of vegetables and fruits in the daily diet.

\section{Metonymies of Sight}

Visual metonymies have essential functions in the rituals of Sagrada Familia group. The changes in the appearance and movements of the body of the luklukan are metonymies of sight of the three benevolent spirits. The thirty-three-year-old luklukan lives in her simple home in a neighborhood populated mostly by relatives and friends. Though her shoulders slightly stooped in a gesture of humility, she has friendly smiling eyes. However, when she calls the name of Lolo Empinito, her whole body begins to tremble. The Sagrada Familia believes that the trembling is the first sign, a metonymy that the spirit of Lolo Empinito is entering the human body. After the trembling, the lips of the luklukan grows a bit thicker and the eyes becomes fierce. The luklukan sits on a special chair that can only be used by Lolo. Then she faces the researcher in an erect, confident posture and starts the conversa- 
tion. The group believes that the presence of Lolo Empinito depends on these visual metonymies.

Moreover, there are two other benevolent spirits that manifest metonymically through the body of the luklukan: Dr. Jose Rizal, a surgeon, and Dr. Felipe Salvador, a dentist. When there is a need for surgery or dental operation, the luklukan calls the spirit of either Rizal or Salvador to possess her body. However, only a few selected members of the group can witness and assist in the operation, which is done in an enclosed area in the home of the luklukan.

The skill of the hands of the luklukan in performing operations is a metonymy of Rizal and Salvador. However, since witnessing the acts is prohibited, the metonymies function as oral narratives that inculcate beliefs. A seventy-seven-year-old female informant narrated how her daughter suffering from a disease was healed through the operation performed by Dr. Jose Rizal in the body of the luklukan:

Nag-usli an kaniya lubot. Diri man po nag-aayad sa doktor. May orasyon na hinimo, pero wara sin hiwa nan dugo an klase san operasyon. Pagkatapos, naayed na an bata ko. (Female Informant, 77 years old).

[Her anus protruded. Doctors could not heal it. A ritual was done and there was no blood during the operation. Afterwards, my daughter got healed.]

Operations exemplified by the narrative above begins with diagnosis through the ritual of tawas. Before calling spirits that will recommend healing plants or a surgical operation, the luklukan and her assistants perform some rituals to diagnose the problem of the patients. The luklukan narrates how the tawas is performed:

Gusto ko lang po i-share saindo an tungkol sa pagtawas. Kami ay naggagamit sin kandila na puti, lana (hali sa lana san niyog), papel o sa iba naman puti na pinggan o sa saday na planggana na may tubi kaupod po an pangadyion. Sa kaso po sin paggamit san papel nan kandila, pagkatapos pugkutan an kandila, Paagihan sin kalayo an likod san papel, upudan ini san pangadyion. Maiimod mo sa harap o sa atubangan kan papel an mga bagay o pagkakataon o kaya kapwa tawo o maging epiritu o mga nilalang na diri nato naiimod parehas san mga 
dwende o iba pang mga elemento, na mao an dahilan san pagkahapdos o naging kamutangan san amo pasyente. Didto kami madesisyon kun anong ritwal o klase san pagbulong an amo ihahatag sa pasyente (Female Informant, 77 years old).

[I just would like to share with you what we do in the ritual of tawas. We use white candle and coconut oil, paper or ceramic plate, and sometimes basin with water. While praying, we use the fire from the candle to burn the back of the paper. We see figures on the front part of the paper-things, people, or spirits that are the causes of the malady of the patient. Then, we decide the appropriate treatment.]

The researcher observed that the ritual of tawas is generally used to determine the cause of the ailment or physical discomfort of the patient. However, when the healers want to know more accurately details of the sickness, they resort to the ritual of himagat. A thirty-two-year-old female informant described the himagat thus:

Nagdesisyon ako na magpahimagat na lang. Yuon baga na naggagamit sin manok. Sa pamamagitan sada naiimod kun nano na parte san lawas san pasyente an may hapdos, kun nano yada na hapdos (Female Informant, 32 years old).

[I have decided to undergo the ritual of himagat. In the ritual, the healer examines the parts of the body of a dressed chicken to detect the sickness in the body of a patient.]

In this ritual, the chicken functions like an ultrasound machine, which provides details about the sick organ. The tawas and himagat are ritualistic visual metonymies of spirits. The findings in the rituals sometimes result in the collaboration with more spirits. Aside from herbal prescription, Lolo occasionally collaborates with other spirits for healing. This is evident in the words of an eighty-year-old informant:

Si lolo an haputon mo. Aram mo may doktor kami doon, doktor talaga pero mga espiritu man. Nakaopera man siya.... An doktor na nagluluklok... si Dr. Jose Rizal nan si Dr. Felipe Salvador. Ini si Dr. Salvador sa ngipon man siya. Mao si Dr. Jose Rizal sa intero siya- sa mata, sa puson, sa kidney. Nakaopera ngani siya (Female Informant, 80 years old). 
[You ask Lolo. You know, we have some doctors here who are also spirits. They are Dr. Jose Rizal and Dr. Felipe Salvador. Dr. Salvador is a dentist. Dr. Jose Rizal is a generalist, for the eyes, bladder, and kidney. He also performs operations.]

Interestingly, however, in contrast to benevolent spirits, there is a negative entity that manifests through metonymies-the Tawo sa Lipod. Sagrada Familia members believe that the tawo sa lipod means any invisible supernatural entity that causes various illnesses and physical discomfort. Thus ailments are usually believed to be metonymies of Tawo sa Lipod. A sixtynine-year-old female informant talked about sicknesses caused by the Tawo sa Lipod. These maladies were healed by the Sagrada Familia, persuading the woman to become a member of the group:

Mga pilay san ako mga apo, mga nagkaurumngan san mga tawo sa lipud. Intiro man sira nag-arayad didi kaya ngani mao ini an daku-dako nako na rason kun akay yadi ako niyan bilang sayo sa miyembro nira (Female Informant, 69 years old).

[My grandchildren had some injuries inflicted by the tawo sa lipod. They all got well. This is the very big reason why I became their member.]

\section{Metonymies of Sound}

The metonymies of sound add more power to the metonymies of sight in representing spirits. The most important sound in the culture of the group is the changed voice of the luklukan, which represents Lolo Empinito.

After a few months, the researcher was granted the opportunity to converse with Lolo Empinito through the luklukan. With a voice that sounds genderless, the female luklukan was surprisingly using another language, Tagalog, a language seldom used in the area. Below is the explanation of Lolo about herbal healing rituals and his collaboration with the spirit of the surgeon Dr. Jose Rizal: 
Tinignan ko po siya. Tapos may isa pong doctor na lumuluklok... si Dr. Jose Rizal. May herbal kami, may doktor din po kami, so iyong Dr. Jose Rizal espiritwal din po siya. Nagsasagawa din... ng mga operasyon. Pero hindi po naming pwedeng ipakita sa inyo (Luklukan).

[So I attended to her (the patient). Then, there was another doctor in the body of the luklukan; we prescribe herbs, but we also have doctors. The spirit of Dr. Jose Rizal is also performing operations. However, we cannot let you see it.]

The connections of Lolo Empinito is not limited to Rizal and Salvador; the great spirit is also associated with lizards. The Sagrada Familia group believes that the sound of a lizard can represent Lolo Empinito anywhere. The voice of Lolo spoke to the researcher about it:

Kung halimbawa ay nasa isang lugar kayo at kailangang kailangan ninyo ang tulong ni lolo, tawagin niyo lamang po si lolo ng tatlong beses. Lolo Empinito o kaya ay lolo lang at sasagot ako sa inyo sa pamamagitan ng butiki. Pero gusto ko ay taos sa puso niyo ang pagtawag sa akin at hindi iyong sinusubukan lang ako (Luklukan).

[If for example, you are in another place and you need the help of Lolo, just call Lolo Empinito or Lolo three times and I will answer through the sound of a lizard. However, you have to call me with sincerity and faith in your heart and not just to test me.]

\section{Metonymies of Touch}

The metonymies of sound and sight are further strengthened by metonymies of touch. A seventy-four-year-old female informant narrated how the healing touch of the luklukan works:

Mao maski and doctor talagang give-up na sila. Dalawang espesyalista sa kidney at saka isa sa dugo ang tumitingin sa kaniya, So nang makahale an doctor, pumasok na kami tapos pumasok si lolo kay Luklukan, hinawakan niya an apo $k o$, dinasalan niya tapos sabi ni lolo gagaling ka na. Sige na an ihi niya. Sabi noong dalawang doctor na espesyalista, it's a miracle! (Female Informant, 74 years old). 
[Yes, even the doctors have given up. Two specialists were treating my grandchild, one for the kidneys, and another for the blood. When the doctors left, we entered the hospital room and Lolo possessed the body of the luklukan. The luklukan touched my grandchild and prayed. Then, afterwards, my grandchild was urinating normally. The two doctors said, "It's a miracle."]

Furthermore, the touch of the water of Dancalan Beach in the neighboring town of Bulusan also functions as metonymy of the powers of Lolo Empinito to drive away malignant spirits from the body of a patient. A sixty-nine-year-old Sagrada Familia female member spoke about the healing power of the sea water of Dancalan:

Sa Dancalan an karigos mi pag may kulam. An Dancalan an may basbas ni lolo na dapat karigusan san pasyente na hale kaniya (Female Informant, 69 years old).

[We let a bewitched patient bathe in the water of Dancalan. Dancalan has the blessing of Lolo as the bathing place for his patients.]

Another metonymy of touch, shared by a female informant in her fifties, is the sacred container called praskera. It is a small circular metal jar with a cover, with a height of around six inches, and size the length of two inches in diameter. Blessed by Lolo Empinito, this jar is believed to be miraculous by Sagrada Familia members. The touch of the jar is a metonymy of the great Lolo. The informant, who was crippled by an accident, claimed that it made her walk:

Yuon na praskera saday lang yoon na sulodan na saday, diri yuon inbubutangan sin lana, pag inhuhuyop niya yuon nabutwa an lana. Yadto lang binilin niya yuon sa ako na praskera inpapairarom ko lang sa pi-ad ko. Pinalakaw ako (Female Informant, 58 years old).

[The praskera is just a small container. We do not put oil in it. We just blow some air into it and it is suddenly filled with oil. The group lent it to me and I put it under my buttocks. It made me walk.] 
In addition, a fifty-four-year-old female informant described the healing touch of the concoction called banyos, as recommended by the voice of Lolo Empinito:

Binulong ako niya sin dinikdik na luya nan yung mga pamahid o banyos na tinatawag nila. Mga pinaghalo halung dahon na tinitimpla sa lana san niyog, alcohol, menthol crystal, alkampor (Female Informant, 54 years old).

[He healed me with banyos, a mixture of ground ginger, leaves of various plants, coconut oil, alcohol, menthol crystal, and camphor.]

\section{Metonymies of Taste}

Members of Sagrada Familia as well as their patients savor the taste of healing plants as metonymies of benevolent spirits. Examples of these are the fruits of malunggay and the leaves of mangosteen and rambutan. The words below are from the conversation with Lolo Empinito who is believed to be speaking through the body of the luklukan:

Kung may sugat din po, o doon sa mga taong may sakit na diabetes, ang gamot naman po dito ay bunga ng malunggay. Ang bunga po ng malunggay, kunin ang buto, ibilad sa araw tapos isasangag at kinakain po siya. Para siyang mani (Luklukan).

[For the treatment of wounds and diabetes, eat the fruits of malunggay. Take and dry the seeds under the sun. Then, fry and eat them like peanut.]

Sa kidney, ang mangosteen po ang mainam para dito. Pwedeng prutas o dahon. Kung sa prutas, kinakain po lamang ito kasama ang buto niya. Ang dahon ng rambutan, nilalaga din po siya. Twenty one na piraso ng dahon ang ilalaga mo sa 1.5 liters na tubig at uminom ng dalawang baso isang araw sa loob ng anim na buwan. Mamimili ka lang po dito sa dalawa kung alin ang iinumin mo (Luklukan).

[For the kidneys, mangosteen is good, both the fruits and the leaves. The fruits must be eaten, including the seeds. In addition, boil twenty leaves of rambutan in 1.5 liter of water and drink one glass of this water twice a day for six months.] 
The fellowship of Sagrada Familia is centered on metonymies of plants. All Sagrada Familia members use plants as remedy for physical ailments, as prescribed by Lolo Empinito. The benevolent function of Lolo Empinito in the human world is largely dependent on metonymies of healing plants. The leaves of all the plants are metonymies of sight since their green leaves are a representation of healing power. The soothing touch of leaves on a painful body part and the taste of varied medicinal concoctions are metonymies of the supreme supernatural herb doctor.

Below is a table of metonymies of plants representing Lolo Empinito's different spirits.

Table 2. Lolo Empinito's Spirit as represented in various plants

\begin{tabular}{|c|c|c|c|c|c|}
\hline $\begin{array}{l}\text { Name of } \\
\text { Plant (Spell- } \\
\text { ing is based } \\
\text { on the pro- } \\
\text { nunciation } \\
\text { of natives) }\end{array}$ & $\begin{array}{l}\text { Common } \\
\text { Name }\end{array}$ & $\begin{array}{l}\text { Scientific } \\
\text { Name }\end{array}$ & $\begin{array}{l}\text { Kind of } \\
\text { Metony my }\end{array}$ & $\begin{array}{l}\text { Manner of } \\
\text { Metonymic } \\
\text { Representa- } \\
\quad \text { tion }\end{array}$ & $\begin{array}{l}\text { Entity Rep- } \\
\text { resented }\end{array}$ \\
\hline Ninu & Ninu & $\begin{array}{l}\text { Barringtonia } \\
\text { sp. }\end{array}$ & $\begin{array}{l}\text { Visual, } \\
\text { touch }\end{array}$ & $\begin{array}{l}\text { Anti-in- } \\
\text { flammatory: } \\
\text { Put leaves on } \\
\text { the aching, } \\
\text { inflamed } \\
\text { body part. } \\
\text { Anti-Can- } \\
\text { cer: } \\
\text { Heat and } \\
\text { grind the } \\
\text { fruit, add } \\
\text { some oil and } \\
\text { apply on the } \\
\text { part of the } \\
\text { body with } \\
\text { cancer. }\end{array}$ & $\begin{array}{l}\text { Lolo } \\
\text { Empinito }\end{array}$ \\
\hline
\end{tabular}




\begin{tabular}{|c|c|c|c|c|c|}
\hline Malunggay & $\begin{array}{l}\text { Tagalog: } \\
\text { Malunggay } \\
\text { English: } \\
\text { Horse reddish } \\
\text { tree }\end{array}$ & $\begin{array}{l}\text { Moringa } \\
\text { loeifera lam }\end{array}$ & $\begin{array}{l}\text { Visual, } \\
\text { touch, taste }\end{array}$ & $\begin{array}{l}\text { Antibiotic: } \\
\text { Grind the } \\
\text { leaves and } \\
\text { green stem, } \\
\text { add some wa- } \\
\text { ter, and put } \\
\text { the juice on } \\
\text { the wound. } \\
\text { For fever: } \\
\text { Mix the juice } \\
\text { with one } \\
\text { teaspoon of } \\
\text { water and } \\
\text { drink the } \\
\text { concoction } 3 \\
\text { times a day. } \\
\\
\text { Cure for } \\
\text { diabetes and } \\
\text { food supple- } \\
\text { ment: } \\
\text { Dry the fruits } \\
\text { under the } \\
\text { sun, and fry } \\
\text { them like } \\
\text { peanuts. } \\
\text { Maximize } \\
\text { the intake of } \\
\text { fruits. }\end{array}$ & $\begin{array}{l}\text { Lolo } \\
\text { Empinito }\end{array}$ \\
\hline Suwa & $\begin{array}{l}\text { Tagalog: } \\
\text { kalamansi } \\
\text { English: } \\
\text { Chinese } \\
\text { Orange }\end{array}$ & $\begin{array}{l}\text { Citrus micro- } \\
\text { carpa Bunge }\end{array}$ & $\begin{array}{l}\text { Visual, } \\
\text { touch, taste }\end{array}$ & $\begin{array}{l}\text { Anti-poison: } \\
\text { Mix lemon } \\
\text { juice with oil } \\
\text { and ginger } \\
\text { and let the } \\
\text { poison victim } \\
\text { drink the } \\
\text { concoction. }\end{array}$ & $\begin{array}{l}\text { Lolo } \\
\text { Empinito }\end{array}$ \\
\hline
\end{tabular}




\begin{tabular}{|c|c|c|c|c|c|}
\hline$L u y-a$ & $\begin{array}{l}\text { Tagalog: luya } \\
\text { English: } \\
\text { Ginger }\end{array}$ & $\begin{array}{l}\text { Zingiber } \\
\text { officinale } \\
\text { Roscoe }\end{array}$ & $\begin{array}{l}\text { Visual, } \\
\text { touch, taste }\end{array}$ & $\begin{array}{l}\text { Anti-poison: } \\
\text { Mix ginger } \\
\text { with lemon } \\
\text { juice with oil } \\
\text { and let the } \\
\text { poison victim } \\
\text { drink the } \\
\text { concoction. } \\
\\
\text { Cure for } \\
\text { cramps, } \\
\text { rheu- } \\
\text { matism, } \\
\text { inflamma- } \\
\text { tion, and } \\
\text { hyperten- } \\
\text { sion: } \\
\text { Grind the } \\
\text { ginger and } \\
\text { put it on the } \\
\text { body part } \\
\text { experiencing } \\
\text { pain. }\end{array}$ & $\begin{array}{l}\text { Lolo } \\
\text { Empinito }\end{array}$ \\
\hline Anonang & $\begin{array}{l}\text { Tagalog: } \\
\text { Anonas } \\
\text { English: } \\
\text { Custard apple }\end{array}$ & $\begin{array}{l}\text { Anona reticu- } \\
\text { late Linn }\end{array}$ & $\begin{array}{l}\text { Visual, } \\
\text { touch }\end{array}$ & $\begin{array}{l}\text { Pain reliev- } \\
\text { er for body } \\
\text { pain due to } \\
\text { child birth } \\
\text { or too much } \\
\text { work: } \\
\text { Put the leaves } \\
\text { on the body } \\
\text { part to ease } \\
\text { the pain. }\end{array}$ & $\begin{array}{l}\text { Lolo } \\
\text { Empinito }\end{array}$ \\
\hline Dusol & $\begin{array}{l}\text { Tagalog: } \\
\text { Dusol }\end{array}$ & $\begin{array}{l}\text { Kaempferia } \\
\text { galanga Linn }\end{array}$ & $\begin{array}{l}\text { Visual, } \\
\text { touch }\end{array}$ & $\begin{array}{l}\text { Cure for } \\
\text { wounds and } \\
\text { infection: } \\
\text { Heat the } \\
\text { leaves with } \\
\text { fire and out } \\
\text { them on } \\
\text { wounds. }\end{array}$ & $\begin{array}{l}\text { Lolo } \\
\text { Empinito }\end{array}$ \\
\hline
\end{tabular}




\begin{tabular}{|c|c|c|c|c|c|}
\hline Sabilaw & $\begin{array}{l}\text { Tagalog: } \\
\text { Sabila } \\
\text { English: } \\
\text { Curacao aloe }\end{array}$ & $\begin{array}{l}\text { Aloe bar- } \\
\text { badensis Mill }\end{array}$ & $\begin{array}{l}\text { Visual, } \\
\text { touch }\end{array}$ & $\begin{array}{l}\begin{array}{l}\text { Cure for } \\
\text { burns: }\end{array} \\
\text { Cut the stem } \\
\text { and put the } \\
\text { juice on the } \\
\text { affected body } \\
\text { part. }\end{array}$ & $\begin{array}{l}\text { Lolo } \\
\text { Empinito }\end{array}$ \\
\hline Mangosteen & Mangosteen & $\begin{array}{l}\text { Garcinia } \\
\text { mangostana }\end{array}$ & $\begin{array}{l}\text { Visual, } \\
\text { touch, taste }\end{array}$ & $\begin{array}{l}\begin{array}{l}\text { Cure for } \\
\text { kidney } \\
\text { ailment: }\end{array} \\
\begin{array}{l}\text { Eat the fruit } \\
\text { including the } \\
\text { seeds. }\end{array} \\
\text { Boil the bark } \\
\text { of the stem } \\
\text { and drink the } \\
\text { liquid one } \\
\text { glass in the } \\
\text { morning and } \\
\text { one in the } \\
\text { evening. }\end{array}$ & $\begin{array}{l}\text { Lolo } \\
\text { Empinito }\end{array}$ \\
\hline Rambutan & Rambutan & $\begin{array}{l}\text { Nephelium } \\
\text { Lappaceum }\end{array}$ & $\begin{array}{l}\text { Visual, } \\
\text { touch, taste }\end{array}$ & $\begin{array}{l}\begin{array}{l}\text { Cure for } \\
\text { kidney } \\
\text { ailment: }\end{array} \\
\text { Boil twenty } \\
\text { one leaves } \\
\text { in } 1.5 \text { liter } \\
\text { of water and } \\
\text { drink the } \\
\text { liquid twice } \\
\text { a day for six } \\
\text { months. }\end{array}$ & $\begin{array}{l}\text { Lolo } \\
\text { Empinito }\end{array}$ \\
\hline Mais & $\begin{array}{l}\text { Tagalog: } \\
\text { Mais } \\
\text { English: } \\
\text { Corn }\end{array}$ & Zea mays $L$. & $\begin{array}{l}\text { Visual, } \\
\text { touch, taste }\end{array}$ & $\begin{array}{l}\text { Cure for } \\
\text { kidney } \\
\text { ailment and } \\
\text { prostate } \\
\text { cancer: }\end{array}$ & $\begin{array}{l}\text { Lolo } \\
\text { Empinito }\end{array}$ \\
\hline
\end{tabular}




\begin{tabular}{|c|c|c|c|c|c|}
\hline Lagundi & $\begin{array}{l}\text { Tagalog: } \\
\text { Mais } \\
\text { Lagundi } \\
\text { English: } \\
\text { Five-leaved } \\
\text { Chaste tree }\end{array}$ & $\begin{array}{l}\text { Vitex negindo } \\
\text { L. }\end{array}$ & $\begin{array}{l}\text { Visual, } \\
\text { touch, taste }\end{array}$ & $\begin{array}{l}\text { Cure for } \\
\text { cough and } \\
\text { cold: } \\
\text { Boil } 21 \text { leaves } \\
\text { in seven } \\
\text { glasses of wa- } \\
\text { ter and drink } \\
\text { the liquid. }\end{array}$ & $\begin{array}{l}\text { Lolo } \\
\text { Empinito }\end{array}$ \\
\hline Kulitis & $\begin{array}{l}\text { Tagalog: } \\
\text { Kulitis } \\
\text { English: } \\
\text { Amaranth }\end{array}$ & $\begin{array}{l}\text { Amaranthus } \\
\text { spinosus } L .\end{array}$ & $\begin{array}{l}\text { Visual, } \\
\text { touch, taste }\end{array}$ & $\begin{array}{l}\text { Cure for too } \\
\text { much air in } \\
\text { the body, } \\
\text { allergies, in- } \\
\text { somnia, and } \\
\text { low blood } \\
\text { prsessure: } \\
\text { Boil kulitis } \\
\text { leaves with } \\
\text { leaves of } \\
\text { artamisa, } \\
\text { sambong, and } \\
\text { guyabano and } \\
\text { drink the } \\
\text { liquid. }\end{array}$ & $\begin{array}{l}\text { Lolo } \\
\text { Empinito }\end{array}$ \\
\hline Artamisa & Artamisa & $\begin{array}{l}\text { Artemisa } \\
\text { vulgaris }\end{array}$ & $\begin{array}{l}\text { Visual, } \\
\text { touch, taste }\end{array}$ & $\begin{array}{l}\text { Cure for too } \\
\text { much air in } \\
\text { the body, } \\
\text { allergies, } \\
\text { insomnia, } \\
\text { and low } \\
\text { blood pres- } \\
\text { sure: } \\
\text { Boil artamisa } \\
\text { leaves with } \\
\text { leaves of ku- } \\
\text { litis, sambong, } \\
\text { and guyabano } \\
\text { and drink the } \\
\text { liquid. }\end{array}$ & $\begin{array}{l}\text { Lolo } \\
\text { Empinito }\end{array}$ \\
\hline
\end{tabular}




\begin{tabular}{|c|c|c|c|c|c|}
\hline Sambong & $\begin{array}{l}\text { Tagalog: } \\
\text { Sambong } \\
\text { English: } \\
\text { Elumea }\end{array}$ & $\begin{array}{l}\text { Blumea } \\
\text { balsamifera }\end{array}$ & $\begin{array}{l}\text { Visual, } \\
\text { touch, taste }\end{array}$ & $\begin{array}{l}\text { Cure for too } \\
\text { much air in } \\
\text { the body, } \\
\text { allergies, in- } \\
\text { somnia, and } \\
\text { low blood } \\
\text { pressure: } \\
\text { Boil sambong } \\
\text { leaves with } \\
\text { leaves of ku- } \\
\text { litis, artamisa, } \\
\text { and guyabano } \\
\text { and drink the } \\
\text { liquid. }\end{array}$ & $\begin{array}{l}\text { Lolo } \\
\text { Empenito }\end{array}$ \\
\hline Guyabano & $\begin{array}{l}\text { Tagalog: } \\
\text { Guyabano } \\
\text { English: } \\
\text { Soursop }\end{array}$ & $\begin{array}{l}\text { Annona } \\
\text { muricata }\end{array}$ & $\begin{array}{l}\text { Visual, } \\
\text { touch, taste }\end{array}$ & $\begin{array}{l}\text { Cure for too } \\
\text { much air in } \\
\text { the body, } \\
\text { allergies, } \\
\text { insomnia, } \\
\text { and low } \\
\text { blood prses- } \\
\text { sure: } \\
\text { Boil guyabano } \\
\text { leaves with } \\
\text { leaves of ku- } \\
\text { litis, sambong, } \\
\text { and artamisa } \\
\text { and drink the } \\
\text { liquid. }\end{array}$ & $\begin{array}{l}\text { Lolo } \\
\text { Empinito }\end{array}$ \\
\hline Cogon & Cogon grass & $\begin{array}{l}\text { Imperata } \\
\text { cylindrica }\end{array}$ & $\begin{array}{l}\text { Visual, } \\
\text { touch, taste }\end{array}$ & 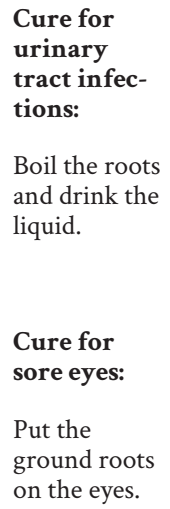 & $\begin{array}{l}\text { Lolo } \\
\text { Empinito }\end{array}$ \\
\hline
\end{tabular}




\begin{tabular}{|l|l|l|l|l|l|}
\hline Kangkong & $\begin{array}{l}\text { Tagalog: } \\
\text { Kangkong }\end{array}$ & $\begin{array}{l}\text { Ipomea aquat- } \\
\text { ic Torsk }\end{array}$ & $\begin{array}{l}\text { Visual, } \\
\text { touch, taste }\end{array}$ & $\begin{array}{l}\text { Cure for } \\
\text { diarrhea: } \\
\text { Put the } \\
\text { ground roots } \\
\text { on the eyes. }\end{array}$ & $\begin{array}{l}\text { Lolo } \\
\text { Empinito }\end{array}$ \\
$\begin{array}{l}\text { English: } \\
\text { Potato Vine, } \\
\text { Swamp } \\
\text { Cabbage }\end{array}$ & & & \\
\hline
\end{tabular}

\section{The Metonymies and the Fellowship for Survival}

Members of Sagrada Familia survive the stress of poverty and disasters by depending on plants and spirits. The words of an eighty-year-old female informant show this dependence:

Habuonon ako magpa-doktor kay apisar na magastuson, deri man namo kaya an magpa-doktor kay pira man hamok an inkikita namo. ... Sa albularyo ... wara pa mga side effects kay an mga ginagamit nira mga herbal plants. Nan dine kami nagkakaarayad (Female Informant, 80 years old).

[I do not want to consult a doctor for it is very expensive and we only have very little earnings. Herb doctors cure us without side effects because only plants are used and we get healed.]

Mountains and bodies of water are believed to be the dwelling places and metonymies of benevolent spirits. Lolo Empinito is believed to be more powerful if he leads rituals against disasters in the natural habitat of the other positive spirits.

A fifty-four-year-old female informant talked about the ritual against disaster:

Kun halimbawa ...may baha na maabot, kun haen yuon na aagihan sin dako san tubi kinakadto namo yoon. Nag-aalay kami san bonay. Tapos naaaraman mi kun matuga an bukid, sinasabihan na kami ni Lolo. Mag-ingat, mangadyi. An sabi ngani sa amo ni Lolo an pinaka primero na sandata nato an mag-pangadyi (Female Informant, 54 years old). 
[If flood is coming, we go to the place where the water passes and we offer eggs. We also know if the mountain (referring to Bulusan Volcano) would erupt, because Lolo tells us. Lolo also tells us to be cautious and to pray to spirits, because prayer is the best weapon.]

\section{Metonymies and Traditional Ecological Knowledge}

The metonymies perpetuate traditional ecological knowledge that serves as cultural models in surviving poverty, sickness, and disasters. These cultural models bind the members of the Sagrada Familia healing group as well as their patients into a fellowship of discourse on survival.

Berkes et al. define traditional ecological knowledge as a cumulative body of knowledge, practice, and belief, evolving by adaptive processes and handed down for generations by cultural transmission. Articulated through material practices, this knowledge is centered on the relationship of human beings with one another and with their environment:

Interest in Traditional Ecological Knowledge has been growing in recent years, partly due to a recognition that such knowledge can contribute to the conservation of biodiversity (Gadgil et al. 1993), rare species (Colding 1998), protected areas (Johannes 1998), ecological processes (Alcorn 1989), and sustainable resource use in general (Schmink et al. 1992; Berkes 1999). Conservation biologists, ecological anthropologists, ethnobiologists, other scholars, and the pharmaceutical industry all share an interest in traditional knowledge for scientific, social, or economic reasons (1251).

Borchgrevink stated that:

The interplay of knowledge, practice and belief in traditional ecological knowledge produces cultural models that determine the way people live. A cultural model is the collective organization and application of cultural knowledge done by community members. "Cultural models . . . organize or encode cultural knowledge, as opposed to individual knowledge.” (226)

Cultural models are grounded on social institutions that overlap in their functions and collectively produce and perpetuate worldviews (Berkes et al. 1251-1262). These institutions are folklore and knowledge carriers 
and the mechanisms for the intergenerational transmission of knowledge. Within the community of the Sagrada Familia group, folklore and knowledge carriers are leaders, elders, and supernatural beings in the local culture. The leaders are the luklukans. The elders are the trusted members of the group who assist in mixing parts of different plants to be used in secret surgical operations. The supernatural beings are Lolo Empinito, Dr. Jose Rizal, Dr. Felipe Salvador, and the tawo sa lipod.

In the culture of Sagrada Familia, there are two main mechanisms for the intergenerational transmission of knowledge. First is the oral narrative tradition carrying metonymic styles of language that articulate and transmit culture. Second is the non-verbal form of language that preserves cultural models through actions of members of a fellowship of discourse and revered objects. In the Sagrada Familia group, the actions are the healing rituals; the revered objects are the plants recommended by Lolo Empinito.

Of the two main mechanisms, oral narrative is the more powerful. Actions and revered objects articulate and preserve discourses; their actual powers, however, are limited to the duration of rituals. It is the oral narrative about the rituals and revered objects that transmit cultural models to the next generation of the fellowship. The oral narratives, the actions in rituals, and the revered objects are all parts of deeply implanted community knowledge.

Following Surrete (557-575), the multiple metonymies and the corresponding cultural practices are articulations of this deeply implanted community knowledge. The collective knowledge in metonymic presence of spirits is deeply etched in the history and culture of the village of Patag, the haven of Sagrada Familia. Patag, which means "plain", was part of a thick forest until the eruption of Bulusan Volcano created a habitable clearing in 1779 which became the home of settlers from Bulusan (History: A Brief history of Irosin 1-10). Elders and healers from the village narrated that some early settlers were from Albay province. They also claim that reliance on benevolent spirits manifesting through different metonymies has been a part of the culture of Patag from the time of the early settlers up to the present. 
This reliance on spirits blending with Christian practices was a way of the early settlers to survive the stress of calamities, sickness, and poverty.

Sagrada Familia healers are devout Christians; their ritual place is decorated with a crucifix and images of saints. They can represent this hybrid belief of Patag. For concerns related to government laws and regulations, people rely on the local politicians of the village. However, to survive the stress of sickness and calamities believed to have been caused by negative spirits, many residents, including some politicians, turn to the healers.

Paradis (245-264) argues that metonymies articulate three ways of seeing the world: objects, events, and abstract entities. These three ways overlap in the fellowship of Sagrada Familia. The spirits cease to be abstract entities when they possess the luklukan. The luklukan, a human vessel controlled by spirits becomes the center of ritualistic events and spiritual survival of the village.

\section{The Cultural Models of Survival}

The ethnobotanical metonymies in rituals and oral narratives articulate four cultural models of survival in the fellowship of discourse of the Sagrada Familia.

First, as previously discussed, is the reliance on spirits and plants to survive sickness, poverty, and disasters.

Second is other-centeredness. The discourse of serving others is articulated in the verbal and non-verbal language of the fellowship, from the spirit-leaders to the ordinary members. The main metonymy, the voice of Lolo, speaks through the luklukan and prescribes healing plants to help the sick and the poor without demanding any fee. Patients give a small amount of money, usually twenty to fifty pesos, as an act of gratitude. Healers voluntarily give patients revered leaves of plants gathered from the surrounding. The group did not ask for anything from the researcher. The research team, though, regularly brought some food to the group to establish rapport.

The third cultural model is peace in fatalism. Lolo Empinito stresses peaceful surrender to fate if neither plants nor his spiritual powers can cure the ailment. This is evident in the story of a fifty-four-year-old female healer: 
Sabi niya sa ako deri ka mahadok ha, tatapaton ta ikaw, kahon na an naimod ko sa asawa mo. Siguro ko ngaya mga saro pa kasemana, deri ka mabigla kay kukuwaon na siya, mamamatay na siya. Mao man ng gayod, pakalipas nin sayo kasemana namatay na siya. Pero diri na ako nabigla. Diri na ako nagkuan sin ang pagkamatay baga niya gare an pahaunon nanggad ako sa kaniya, dahil apisar san tanggap ko naman siya, insasabi man sa ako ni lolo na an buhay talagang irog sada dapat handa ka (Female Healer, 54 years old).

[He told me (referring to Lolo Empinito), do not be afraid. I say to you that I have seen the coffin of your husband. Do not get shocked, for he will be taken and he will die. It really happened. After one week, he died. I was no longer surprised. I did not crave for him with intense depression, because aside from my acceptance of fate, Lolo was telling me that we must be ready to accept the adversities in life.]

The fourth cultural model is happiness in kinship, simplicity, and nature. Despite poverty and frequent disasters, members of Sagrada Familia find happiness in kinship. The group is like a big extended family. They give comfort to each other through herbal cure and the telling of oral narratives about the benevolent powers of spirits. They are contented with material simplicity.

The spirits inherent in all cultural models just exist through metonymies and cannot be verified scientifically. However, the reliance on healing plants, kinship, other-centeredness, simplicity, and acceptance of fate, are positive virtues useful for survival; these are cultural models that can be adopted by other groups in harsh environments.

\section{Philippine Ethnobotany through the Lens of Language and Culture}

There are few studies in Philippine ethnobotany and most of these are utilitarian. Rotor (18-70) focused on the Ilocos region; Prigge et al. (1-4) on the foothills of Mt. Pangasugan on the island of Leyte; Buot (1-10) on the biodersity of Mt. Mayon in Albay; Angagan et al. (31-38) on Apayao, northern Luzon; Olowa et al. (1442-1449) on Higaonon tribe in Rogongon in Iligan City; Blasco et al. (166-172) in the province of Surigao del Sur in Southern Mindanao; Morilla, et al. (38-43) in the three (3) Barangays of Dumingag, 
Zamboanga del Sur, Philippines; Ong, et al. (228-242) on the Ati Negrito indigenous people in Guimaras Island; and Pinarok et al. (101-108) at the Samar Island Natural Park.

The researches mentioned above focus on collection and identification of plant species used for utilitarian reasons like food and cure for physical ailments. They also elucidate on the methods used in the production and processing of these plants. These researches are significant for pharmacological, medicinal, and economic reasons; they provide avenues for cheap yet effective traditional healing and survival. However, they have not deeply delved into cognitive ethnobotany to explore the cultural symbolisms and social structures and examine the symbolic ways plants are perceived in a particular community.

A way to cognitive ethnobotany is to examine how the system of beliefs, language, and material practices of a group of people show the role of plants as mediators in the power relations between human beings and supernatural entities.

In 2007, Jesus Cyril M. Conde, Maria Aurora Azurin-Conde, and Ramona Renegado published Hybrid Christianity in the Oral Literature and Ethnobotany of the Agtas of Mt. Asog in the Bikol Region of the Philippines. With the methodology of descriptive research design combining participant observation, interviews, and questionnaires, the paper has 40 informants from 8 Agta tribes on Mt. Asog in the Bikol Region. The findings reveal a hybrid culture consisting of indigenous pre-colonial beliefs and Christian elements. This culture shows the indigenous belief in the role of plants as mediators in the power relations between people and invisible beings. This mediating function is traced from pre-colonial time to the present in the Bikol region of the Philippines (255-272).

This 2007 paper argues that the power of plants is still present among tribal people on Mt. Asog. Negative supernatural beings manifest as animals or plants and possess the bodies and minds of people. However, people can also use the power of some plants to drive away the spirits and cure the sick. Nevertheless, although grounded on primary data from oral literatures and medicinal plants of eight tribes on Mt. Asog in Camarines Sur and historical 
documents, the paper does not employ a coding method for the systematic analysis of the functions of language and culture.

In 2017, Jesus Cyril M. Conde and Maria Aurora A. Conde (1-33) extended the study by purposively focusing on a single tribe on Mt. Asog which was not covered in the 2007 research. This tribe called itom or "black" is the rendezvous of spirit-guided herbal healers from different tribes on the mountain. This study first employed the metonymic codes in language that construct and perpetuate fellowships of discourse. It unveiled the roles of plants as metonymies of the benevolent supernatural Tawong Lipods and Diwatas. These supernatural beings are believed to be the sources of positive power of plants as food, cure for physical ailment, and instrument to drive away negative spirits. The metonymies construct an ethnobotanical fellowship of discourse that includes all the members of the tribe.

The present study extends the 2017 project by employing the same coding methodology on a different cultural group, which was also purposively chosen: the Sagrada Familia of Irosin, Sorsogon. Both studies show that styles of languages like metonymies are contained in material practices and oral literature that construct cultural models and fellowships of discourse. These fellowships rely on plants, spirits, kinship, and nature for survival and happiness.

The functions of metonymies in Philippine history and culture can be traced from the belief in anito spirits, to religious groups on Mt. Banahaw, to contemporary folklore in the Bikol region.

In early Philippines, supernatural beings called anitos were represented by both natural and man-made metonymic objects. Tomas Ortiz (qtd. in Sturtevant 24) provides details of these metonymies of anitos:

Volcanoes, precipices, chasms, waterfalls, caverns, pools, forest glens, gnarled trees, eroded rocks, and surf swept reefs were all regarded as the habitation of gods and ancestral phantoms. .. . Great and minor denizens of the underworld were all recognized in religious observances. Barangay people fashioned wood and metal images in their honor, placed the idols in houses and fields, and regularly paid homage to them. No effort was made to distinguish between the spirits and their material world. Both were called anitos. (24) 
In the belief of people on Mt. Banahaw, blindness is a metonymy of the power of the mountain to prevent somebody from returning to the lowland. Agripino Lontok, a rebel against Spanish colonial authorities became blind when he went to the mountain to acquire anting-anting or "talisman." Lontok got supernatural powers but he maintained his rebel lair on the mountain. The mountain also revealed its secret places and powers to Lontok through a metonymic voice popularly known as santong boses. The santong boses is the spirit of the mountain believed to have given powers to Lontok. (Gorospe 205-206).

Little birds are also believed to be metonymies of the power of Mt. Banahaw. Members of the Mt. Banahaw-based religious group, Samahang Tatlong Persona Solo Dios, believe that their founder Agapito Ilustrisismo got his supernatural powers from seven tiny birds that entered his body (Marasigan qtd. in Del Pilar-Garcia 13-14).

In the Bikol Region of the Philippines, Loza et al. (1589-1592) expose the function of metonymy in the village of Cagliliog in Tinambac town, Camarines Sur province. In Cagliliog, supernatural beings called Tawong Lipod manifest to people and control beliefs and practices through representative metonymies like sounds of animals, dreams, and physical and mental ailments.

The works of Ortiz, Sturtevant, Gorospe, Marasigan, and Del PilarGarcia cited above have revealed how supernatural powers in Philippine culture are represented by metonymic symbols. Nevertheless, they have not directly used the term "metonymy." In contrast, Loza et al. used the term "metonymy" in cultural analysis. These studies are admirable in unveiling the role of language in the articulation of culture and perpetuation of corresponding material practices. However, these papers did not focus on the role of symbolic language in general and metonymy in particular in the relationships between plants, people, and culture. This present study attempted to explore this relationship through the focus on language and culture in the study of Philippine ethnobotany.

Using grounded theory methodologies of participant observation, substantive coding, and theoretical coding, this study can be expanded by 
exploring the ethnobotany, oral literature, language, and history of groups of healers in the rest of the Philippines. These healers have their own oral history, culture, and ethnobotany. They belong to the silent parts of Philippine history and culture.

In addition, the language and culture of ethnobotany in other forest and agricultural areas of Bikol and the Philippines can be studied in bigger interdisciplinary projects. 


\section{Works Cited}

Angangan, Juana S., et al. "Ethnobotany of the plant resources in Conner, Apayao, Northern Luzon, Philippines." Journal of Nature Studies, vol. 9, no. 1, 2010, pp. 31-38.www.researchgate.net/publication/236339999_Ethnobotany_of_the_ plant_resources_in_Conner_Apayao_northern_Luzon_Philippines.

Balangkod, Teodora D., and Kryssa D. Balangkod. "Ethno-Medicinal Plants in Bayabas, Sablan, Benguet Province, Luzon, Philippines.” Electronic Journal of Biology, vol. 11, 2015, pp. 63-73. ejbio.imedpub.com/ethnomedicinal-plants-in-bayabas- sablan-benguet-province-luzon-philippines. php?aid $=7365$.

Balick, Michael, and Paul Allan Cox. Plants, People and Culture: The Science of Ethnobotany. Scientific American Library, 1996.

Biernacki, Richard. "Language and the Shift from Signs to Practices in Cultural Inquiry." History and Theory, vol. 39, no. 3, 2000, pp. 289-311. www.jstor.org/ stable/2678013.

Berkes, Fikret, et al. "Rediscovery of Traditional Ecological Knowledge and Adaptive Management." Ecological Applications, vol. 10, no. 5, 2000, pp. 1251-1262.www.jstor.org/stable/2641280.

Blasco, Freddie A., et al. "A Survey of Ethno-Medicinal Plants in Surigao Del Sur Mountain Range, Philippines.” International Journal of Pure and Applied Science, vol. 2, no. 4, 2014, pp. 166-172. https://www.semanticscholar.org/ paper/A-Survey-of-Ethnomedicinal-Plants-in-Surigao-Del-Blasco-Guzman/0ad648feddf10e34ae64fa379c582d4ab102ece0.

Buot, Inocencio Jr. "An Ethnobotanical Study of the Plant Biodiversity of Mt. Mayon, Bicol Peninsula, Albay, Philippines." Journal of Nature Studies, vol. 8, no. 1, 2009, pp. 1-10. https://www.researchgate.net/publication/236340051_ An_ethnobotanical_study_of_the_plant_biodiversity_of_Mt_Mayon_Bicol_ Peninsula_Albay_Philippines.

Borchgrevink, Axel. "Clean and Green: Indigenous Knowledge and Cultural Models in a Philippine Community." Ethos, vol. 67, no. 2, 2002, pp. 223-244. www. tandfonline.com/doi/pdf/10.1080/00141840220136837.

Camacho, Leni D., et al. "Traditional Forest Conservation Knowledge/Technologies in the Cordillera, Northern Philippines." Forest Policy and Economics, vol. 22, 2012, pp. 3-8.www.sciencedirect.com/science/article/pii/ S138993411000078X.

Castaño, Jose. "Breve Noticia Acerca del Origen, Religion, Creencias y Superticiones de Los Antigous Indios del Bicol.” Archivo del Bibliofilo Filipino. Edited by Wenceslao E. Retana, Madrid: Viuda de Minuesa de los Rios, 1895. 
Conde, Jesus Cyril M., et al. "Hybrid Christianity in the Oral Literature and Ethnobotany of the Agtas of Mt. Asog in the Bikol Region of the Philippines." Socio-Cultural and Economic Challenges. Edited by Carmencita T. Aguilar, International Federation of Social Sciences Organizations (IFSSO), 2007, pp. 255-272.

Conde, Jesus Cyril M., and Maria Aurora A. Conde. Metonymies of Ethno-botany and the Fellowship Discourse of Itom Tribe on Mt.Asog, Iriga City, Philippines. University Research Council, Ateneo de Naga University, 2017.

Cotton, C.M. Ethno-botany: Principles and Applications. John Wiley and Sons, 1996.

Del Piar-Garcia, Maria Lourdes. The tatlong persona solo dios and Inggo La Fuente movements: a cultural heritage in the Philippines. Maria Lourdes Del Pilar-Garcia, (n.d.). bethel.librarika.com/search/detail/522251.

Female Informant, 32 years old. Interview. Conducted by Jesus Cyril M. Conde, 15 March 2018.

Female Informant, 54 years old. Interview. Conducted by Jesus Cyril M. Conde, 15 March 2018.

Female Informant, 54 years old. Interview. Conducted by Jesus Cyril M. Conde, 18 January 2018

Female Informant, 69 years old. Interview. Conducted by Jesus Cyril M. Conde, 28 January 2018.

Female Informant, 74 years old. Interview. Conducted by Jesus Cyril M. Conde, 21 January 2018.

Female Informant, 77 years old. Interview. Conducted by Jesus Cyril M. Conde, 08 February 2018.

Female Informant, 80 years old. Interview. Conducted by Jesus Cyril M. Conde, 06 January 2018

Foucault, Michel. The Archaeology of Knowledge and the Discourse on Language.

Pantheon Books, 1972. monoskop.org/images/9/90/Foucault_Michel_Archaeology_of_Knowledge.pdf.

Gorospe, Vitaliano R., S.J. "Mount Banahaw: The Power Mountain from Ritualism to Spirituality.” Philippine Studies, vol. 40, no. 2, 1992, pp. 204-218. www.jstor. org/stable/42633309.

Haig, Brian. "Grounded theory." Encycopedia of Measurement and Statistics. Edited by Neal J. Salkind, SAGE Publications, Inc., 2007, pp. 419-421. methods.sagepub. com/reference/encyclopedia-of-measurement-and-statistics.

"Estimates and Future Projections of Demography." 15 Sept. 2017, irosin.gov.ph/ category/government/profile/municipal-profile.

"History: A Brief History of Irosin.” 2012, irosin.gov.ph/category/government/ profile/municipal-profile.

Hornedo, Florentino. Research Methodology in Philippine Oral Literature. Literature and Language Studies Department, Ateneo de Naga University, 2015. 
Keller, Reiner. Doing Discourse Research. SAGE Publications, Ltd., 2012.

Lisboa, Marcos de. Vocabulario de la Lengua Bicol. Manila: Colegio de Santo Tomas, 1865.

Loza, Camille Ann A., et al. "Metonymies of Tawonglipod in Cagliliog, Tinambac Camarines Sur: Counter-Memory to Christian Hegemony in Bikol, Philippines." Advanced Science letters, vol. 2, nos. 5-6, 2016, pp. 1589-1592. www. researchgate.net/publication/306024141_Metonymies_of_Tawonglipod.

Luklukan, 32 years old. Interview. Conducted by Jesus Cyril M. Conde, 18 January 2018.

Manuel, E. Arsenio. Guide for the Study of Philippine Folklore. Philippine Folklore Society, 1985.

Morilla, Lady Jane G., et al. "Medicinal Plants of the Subanens in Dumingag, Zamboanga del Sur, Philippines." International Conference on Food, Biological and MedicalSciences, 2014, pp. 38-43. http://dx.doi.org/10.15242/IICBE.C0114577.

Olowa, Lilibeth F., et al. "Medicinal Plants Used by the Higaonon tribe of Rogongon, Iligan City, Mindanao, Philippines.” Advances in Environmental Biology, vol. 6, no. 4, 2012, pp. 1442-1449. www.aensiweb.com/old/ aeb/2012/1442-1449.pdf.

Ong, Homervergel G., and Young-Dong Kim. "Quantitative Ethnobotanical study of the Medicinal Plants Used by the Ati Negrito Indigenous Group in Guimaras Island, Philippines." Journal of Ethnopharmacology, vol. 157, 2014, pp. 228-242. doi.org/10.1016/j.jep.2014.09.015.

Orden, Abraham. "Metaphor/Metonymy." The Chicago School of Media Theory, 2018. https://lucian.uchicago.edu/blogs/mediatheory/keywords/metaphormetonymy/.

Paradis, Carita. "Where Does Metonymy Stop? Senses, Facets, and Active Zones." Metaphor and Symbol, vol. 9, no. 4, 2004, pp. 245-264. www.tandfonline.com/ doi/abs/10.1207/s15327868ms1904_1.

"Patag, Irosin, Sorsogon Profile - Phil Atlas."https://www.philatlas.com/luzon/r05/ sorsogon/irosin/patag.html (Retrieved April 8, 2021).

Prigge, Vanessa, et al. "Ethnobotanical Survey Among Farmers in Leyte, Philippines, and Comparison with Indigenous Filipino Plant Lore.” Conference on International Agricultural Research for Development, 2005, pp. 1-4. www. tropentag.de/2005/abstracts/full/587.pdf.

Pinarok, Neal Alejandro, et al. "Inventory and Ethnobotanical Study of medicinal plants at Samar Island National Park, Philippines." International Journal of Pure and Applied Science, vol. 3, 2014, pp. 101-108. www.semantocscholar.org.

Ramos, Benito. NDRRMC Update: A Report on the Lahar Flow in Irosin, Sorsogon. National Disaster Risk and Management Council, 2011. http://www.ndrrmc. gov.ph/attachments/article/1618/Report_on_the_Lahar_Flow_in_Irosin_ Sorsogon_as_of_15March2011.pdf. 
Renegado, Ramona, et al. Ethnobotany of the Agtas in Mount Asog. Ateneo de Naga University Library, 2002.

Rotor, Abercio Valdez. "Ethnobotany of Maguey in the Ilocos Region, Philippines." Journal of Graduate Research (Philippines), 1983, pp. 18-70. http://agris.fao.org/ agris-search/search.do? recordID=XB8410572.

Sturtevant, David R. Popular uprisings in the Philippines 1840-1940. Cornell UP, 1976.

Surrete, Leon. “Metaphor and Metonymy: Jakobson Reconsidered." University of Toronto Quarterly, vol. 56, no. 4, 1987, pp. 557-575. https://www.utpjournals. press/doi/abs/10.3138/utq.56.4.557.

"Volcano Information Materials." Philippine Institute of Volcanology and Seismology. https://www.phivolcs.dost.gov.ph/. Retrieved March 8, 2021. 